American Journal of Environmental Science and Engineering
2021;5(3): 53-62
http://www.sciencepublishinggroup.com/j/ajese
doi: 10.11648 /j.ajese.20210503.11
ISSN: $2578-7985$ (Print); ISSN: $2578-7993$ (Online)

\title{
Flood Inundation Mapping and Risk Analysis Case of Finchaa Lake
}

\author{
Jiregna Nugusa Duressa, Motuma Shiferaw Regasa \\ Department of Hydraulic and Water Resource Engineering, Wollega University, Nekemte, Ethiopia \\ Email address: \\ jnyonat@gmail.com (J. N. Duressa),motumashiferaw@gmail.com (M. S. Regasa)
}

To cite this article:

Jiregna Nugusa Duressa, Motuma Shiferaw Regasa. Flood Inundation Mapping and Risk Analysis Case of Finchaa Lake. American Journal of Environmental Science and Engineering. Vol. 5, No. 3, 2021, pp. 53-62. doi: 10.11648/j.ajese.20210503.11

Received: July 1, 2021; Accepted: July 27, 2021; Published: August 4, 2021

\begin{abstract}
Mapping Flood inundation is used to inform that the flooding area and also used to guide the administrative to undertake control measurements of flood risks and also used for planning future investments. Some of structures affected by flooding are: crop land, roadways, cultivation land, cattle's and the like. For this research work Hydraulic models (Hydrologic Engineering Center's River Analysis System, Geographical Information System tools and Hydrological Engineering Centers for Geographical river analysis system software's were used for developing flood prone map for different return periods and flood risk analysis. This study is use to develop flood inundation map for flood risk management plan and it helps to give effective and urgent action plan for surrounding community that requires accurate prediction of inundation levels. The research outcome can be used to develop emergency action plan that minimize the flood risk of the area for the lakes based on the flood inundation map developed and used to inform the surrounding community the level of flood and its affect and the research finding will support other researchers to do other analysis over the lake. Geometric data were generated form the Google map using different models. The 100-year return period of annual average flood discharge and probable peak flood have been used for the calculation of hydraulic parameters. The flood risk assessment map delineated over $280 \mathrm{~km}^{2}$ shows that where shows very low land area of the lake were affected by flood and it is now important that the concerned body should take immediate measurements. The flood inundation prone area classifies the flooding area into high, medium and low risk areas and from the result the downstream both side of Finchaa Lake highly affected by the flooding. Therefore, the downstream area of the Lake needs immediate solutions by the concerned body, should take immediate action to mitigate such happening.
\end{abstract}

Keywords: DEM, GIS, Google Map, Inundation, HEC-RAS, HEC-GeoRAS, Flood

\section{Introduction}

Flood inundation mapping (FIM) is required to understand the effects of flooding in an area and on important structures such as roadways, streets, buildings, crop land, cattle's and the like. FIM provides important information, like depth, width and spatial extent of flooded zones, required by the administrative authorities to inform the citizens about the major flood prone areas and adopt appropriate flood risk management strategies.

Floods are costly natural disasters causing fatalities, damages to life, property, communications, transportation, and critical infrastructures [1]. Flood is defined as a water flow with high discharge, which water rises and drowning out its land around that are not usually under water. Annually, nearly 99 million people worldwide were affected by floods during the period 2000-2008 [2]. Floods can happen anywhere with its effects in developing countries due to their low incomes, poor housing facilities, inadequate warning systems and preparedness. In addition to that, climate change will have a key role in changing the hydrological cycle through affecting precipitation, surface runoff, soil moisture, and the recharge rates of ground water and by intensifying and accelerating it, which may increase the magnitude and flood frequency of future. Flood inundation maps are dependent on the topographic and geomorphologic features of drainage basin of lake [3]. Floodplain modeling is a relatively new and applied method in river engineering discipline and is essential for prediction of flood risks, and the purpose of managing and performing all river training practices [4]. For this Study, integrating of HEC-RAS, HECGeoRAS and ArcGIS were used to prepare inundation map 
(inundation extents and depths) within different return periods and analysis flood risk of the area. The Hydrologic Engineering Center River Analysis System (HEC-RAS) model was developed by the U.S. Army Corps of Engineer. This research conducted flood risk and mapping its prone area and used for to attempt flood management plan.

\subsection{Statement of Problem}

Flood can result in huge damages to downstream areas of the lakes and both sides of lakes having low elevation level. Floods are costly natural disasters causing activities, damages to life, property, communications, transportation, and critical infrastructures [1]. Flood is defined as a water flow with high discharge, which water rises and drowning out its land around that are not usually under water. Annually, nearly 99 million people worldwide were affected by floods during the period 2000-2008 [2]. Due to lack of understanding of hydrological parameters, and capacity of flood that occurs due to high precipitation damages human life, crop area, transportation, critical infrastructures like bridge, dam, residential house and others through the world. Therefore, the reason that motivates me to select this topic for farther study of research and it is sensitive to model flood inundation prone area of lake and analysis flood and that protects the community from damages that caused by flood. Studying of the flood inundation map of lake helps to give effective and urgent action plan that requires accurate prediction of inundation levels.

\subsection{Objective of the Study}

\subsubsection{General Objective}

The general objective of this research is Flood Inundation Mapping and Risk Analysis using GIS, HEC-RAS and HECGeoRAS model case of Finchaa Lake.

\subsubsection{Specific Objective}

The specific objectives of this study are:

1. To develop flood inundation mapping prone area of the lake.

2. To analysis flood risk around the lake.

\subsection{Scope of the Study}

The scope of the study is extended from upstream end of the river to point of dam constructed. In this study the analysis is proposed on the prediction of flood prone area and risk analysis due to existence of high flood. HEC-RAS model is used to estimate peak flood, water surface level (water depth), top width of water, and etc. for downstream area and both bank side of lake.

\section{Methodology}

\subsection{Study Area}

The Finchaa Lake is artificial lake that constructed for the purpose of irrigation and hydropower with creating reservoir volume of $406 \mathrm{Mm}^{3}$ at a full reservoir level of elevation
$2220 \mathrm{~m}$ (m.a.s.l) and which is constructed in 1973 E.C. In 1987, Amarti River is diverted to Finchaa reservoir through a tunnel to fulfill the requirement of electricity generation [5]. The spillway is designed to handle reservoir overflow resulting from the occurrence of the excess flood. During construction of Amarti Diversion Project, the crest elevation of the uncontrolled spillway has been raised by $2 \mathrm{~m}$. Providing an additional storage capacity of about $219 \mathrm{Mm}^{3}$ through tunnel, the total storage capacity of the Reservoir becomes $625 \mathrm{Mm}^{3}$ at elevation of $2222 \mathrm{~m}$ (m.a.s.l). The climate of Finchaa watershed is tropical highland monsoon with an average annual rainfall of $1604 \mathrm{~mm}$. Most of the rain falls during the month of June to September. The crest length of the Finchaa dam is $340 \mathrm{~m}$ with a maximum height, top width and crest elevation $22.2 \mathrm{~m}, 7 \mathrm{~m}$ and $2225 \mathrm{~m}$ (m.a.s.1) respectively. The bed level of reservoir is $2207 \mathrm{~m}$ from mean see level. Its Reservoir area at $2222 \mathrm{~m}$ (m.a.s.l) is $170 \mathrm{~km}^{2}$.

\subsection{Methods}

In order to answer the above research objectives, models used are: GIS, HEC-RAS and HEC-GeoRAS for digitalization of topographical data and digital elevation model, simulation of flood flows at different return periods and preparation of flood inundation mapping respectively. In addition, flood frequency analysis is used to determine peak flood flow which used as upstream boundary condition of the Hydraulic model.

The HEC-GeoRAS floodplain mapping hydraulics model has been used based on the observed peak flow data from some selected gauging stations. The DEM and other important components of flood risk area and inundation extent mapping have been analyzed using ArcGIS and HECGeoRAS.

\subsubsection{Flood Risk Assessment}

The purpose of flood risk assessment is to identify the areas within a development plan that are at risk of flooding based on factors that are relevant to flood risks. The selected factors for flood risk assessment are: flood depth, flood width and time of occurrence through HEC-GeoRAS and indicating high, medium and low risk areas [9]. River flood risk management is the process under which different bodies try to reduce the current and the future vulnerability of human society to natural hazards [11].

\subsubsection{Inundation Area Mapping}

Flood prone area is expected to change due to intensification of the hydrological cycle as a result of climate change [10]. The DEM (digital elevation model) was processed to create the TIN (triangular irregular network). After that, the river cross-sections through the lake, stream centerline, stream bank lines, flow lines, and other river geometry information were extracted from the TIN for the HEC-GeoRAS model. At the same time, the land use was processed to get the Manning's n value for the individual cross-sections. After the RAS geometry data preparation, the HEC-GeoRAS model was used to generate the RAS GIS 
import file (final river geometry file of lake) that can be used as input for HEC-RAS.

HEC-RAS model is used for checking the cross-section; editing the river geometry of lake, and making final correction of the river geometry. Flood inundation mapping is an important tool for municipal and urban growth planning, emergency action plans, flood insurance rates and ecological studies [12]. HEC-RAS generated water level for different return periods. The water surface level for each return period has been exported in HEC-GeoRAS for final inundation area mapping along the river.

\subsubsection{HEC-RAS Model}

The Hydrologic Engineering Center's River Analysis System (HEC-RAS) has been developed by US Army Corps of Engineers Hydrologic Engineering Center and it is a free downloadable with other supportive documents about how to use the model for flooded area mapping. The input data required for HEC-RAS model simulation are: boundary condition. Inflow/ peak flood flow, manning roughness coefficient and geometry file.

\subsubsection{HEC-GeoRAS Model}

The HEC-GeoRAS is a GIS extension with a set of procedures, tools, and utilities for the preparation of river geometry GIS data to import into HEC-RAS and it is used to generate the final inundation map for the indication of risk areas. The input data required for the River geometry preparation using the HEC-GeoRAS model are Triangular Irregular Network (TIN), DEM, and land use.

The lakes stream centerline, bank lines, flow path centerlines, and cross section cut lines should be digitized from DEM using Arch GIS. The lake and cross-section data layers are created with predefined attribute tables that are manually populated in the case of the river and reach names, while all other attributes are automatically calculated by the
HEC-GeoRAS [6]. The interface extracts the geometric data in an.xml format that is imported into HEC-RAS and after edited and simulated again it return back to HCE-GeoRAS model of GIS extension.

The exported geometric data from GIS is edited in the HEC-RAS model using the HEC-RAS editor tools. The HEC-RAS consists of a number of editors tools to deal with different functions in the modeling process. For this study only the geometric, steady flow data, cross-section, and steady flow simulation editors are used.

\subsection{Data Processing and Analysis}

Since all information to be collected is relevant/ necessary, it is mainly doing some data processing \& analysis. Data collected and analyzed in terms of tables, graphs, numbers, models and words.

The flood inundation modeling of the lakes includes comparison of different parameters based on magnitude they affect environmental, social and economy of the society. Hence, bases on experience and likely impact on surrounding environment, different weights are assigned to all the parameters. The larger the weight, the more important is the criteria in the overall utility. Data will be processed by integration of GIS, HEC-GeoRAS and HEC-RAS model.

The annual rainfall of Finchaa catchment ranges from $1367 \mathrm{~mm}$ to $1842 \mathrm{~mm}$, with the lower rainfall occurring in the northern lowlands, and the higher rainfall is greater than $1500 \mathrm{~mm}$ occurring in the southern and western highlands of the sub-basin. The soil type and stream flow data were collected from the Ministry of Water and Energy, Ethiopia. The digital elevation model (DEM) and land use were also downloaded from the United States Geological Survey (USGS). The daily stream flow data was collected from the available gauging stations.

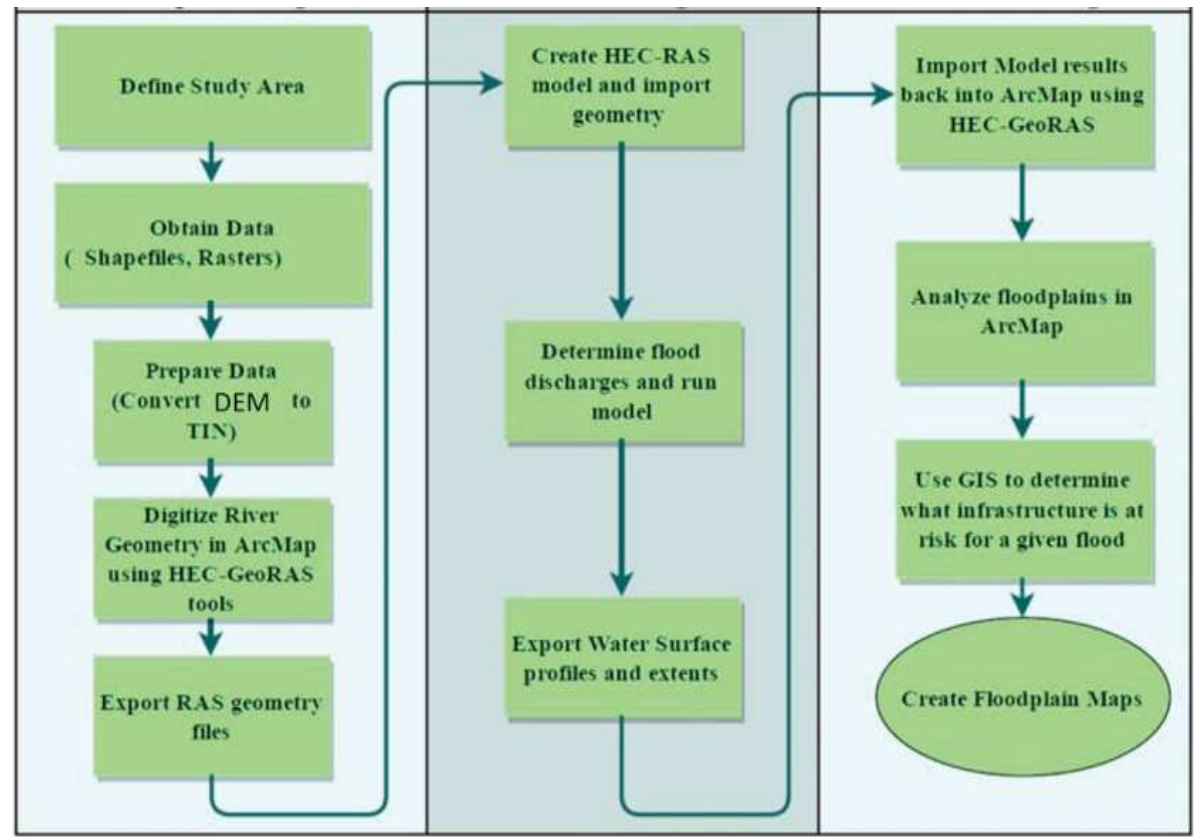

Figure 1. The general method/ process to model Flood Inundation Mapping using ArcGIS, HEC-GeoRAS and HEC-RAS. 


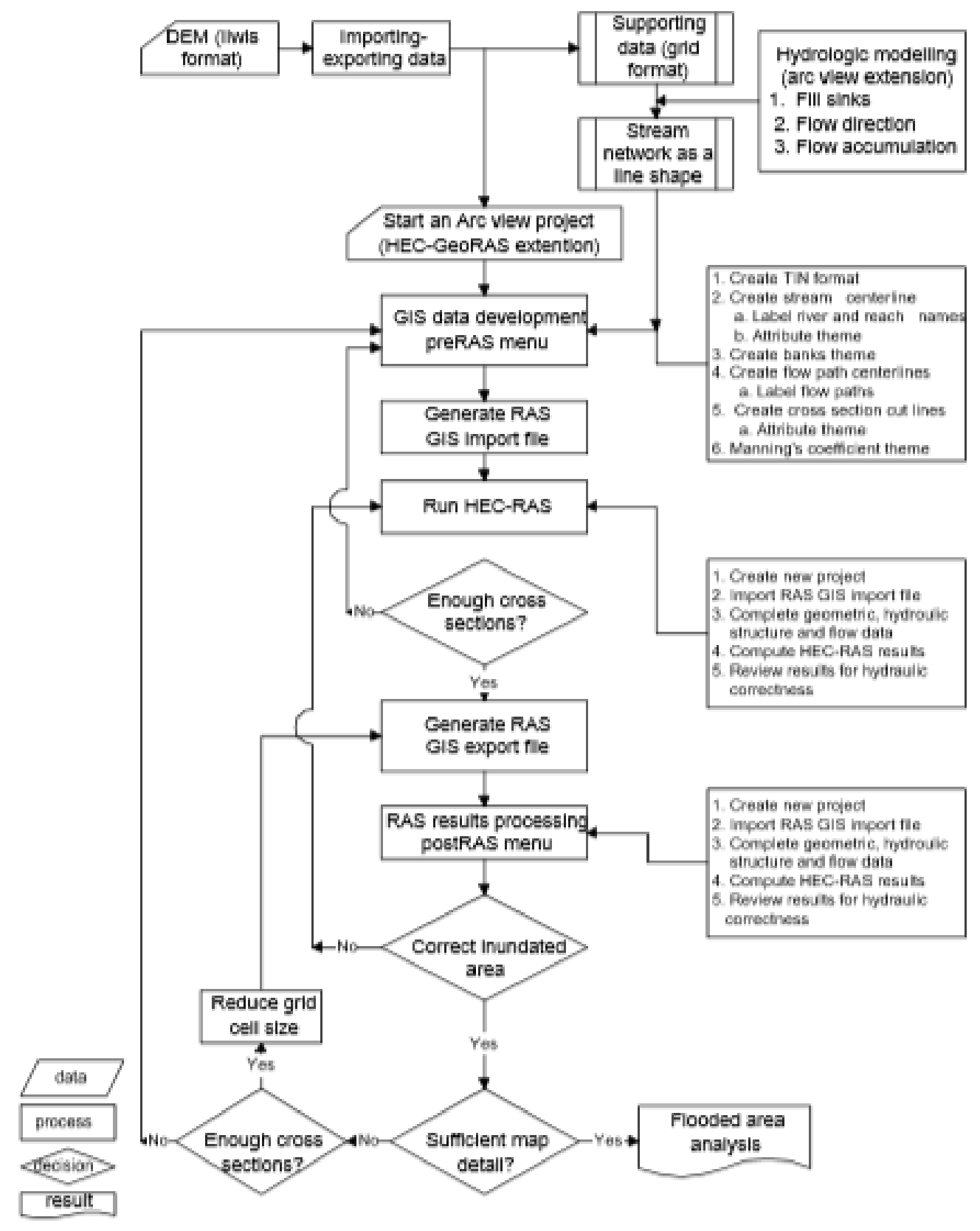

Source: (Modified from Usage, 2000)

Figure 2. Technical Flowchart of River/Lake Flood Modeling.

\subsection{DEM Generation}

A digital elevation model (DEM) is a digital representation of the Earth's liberation that consists of an ordered array of elevations relative to a datum, and referenced to a geographic coordinate system [7]. DEMs are the main source to produce information of land topography. It provides elevation information that is useful for many environmental applications including hydrologic modeling and flood management planning and also used to provide the opportunity to model, analyze and display phenomenon related to topography and other surfaces [8].

For this study, the Digital Elevation Model had been created using point interpolation from Google earth in the Arch GIS software. Contour and TIN data which used for geometric data creation where created from Digital Elevation Model using Arch GIS software tools.

\subsection{Geometric Data Input}

The basic geometric data consists of establishing the connectivity of the river system through the lake; crosssection data, flood flow path; banks; reach length; energy loss coefficients, stream junction information; storage areas; and 2Dflow areas, hydraulic structure data (bridges, culverts, spillways, etc.) [6]. 


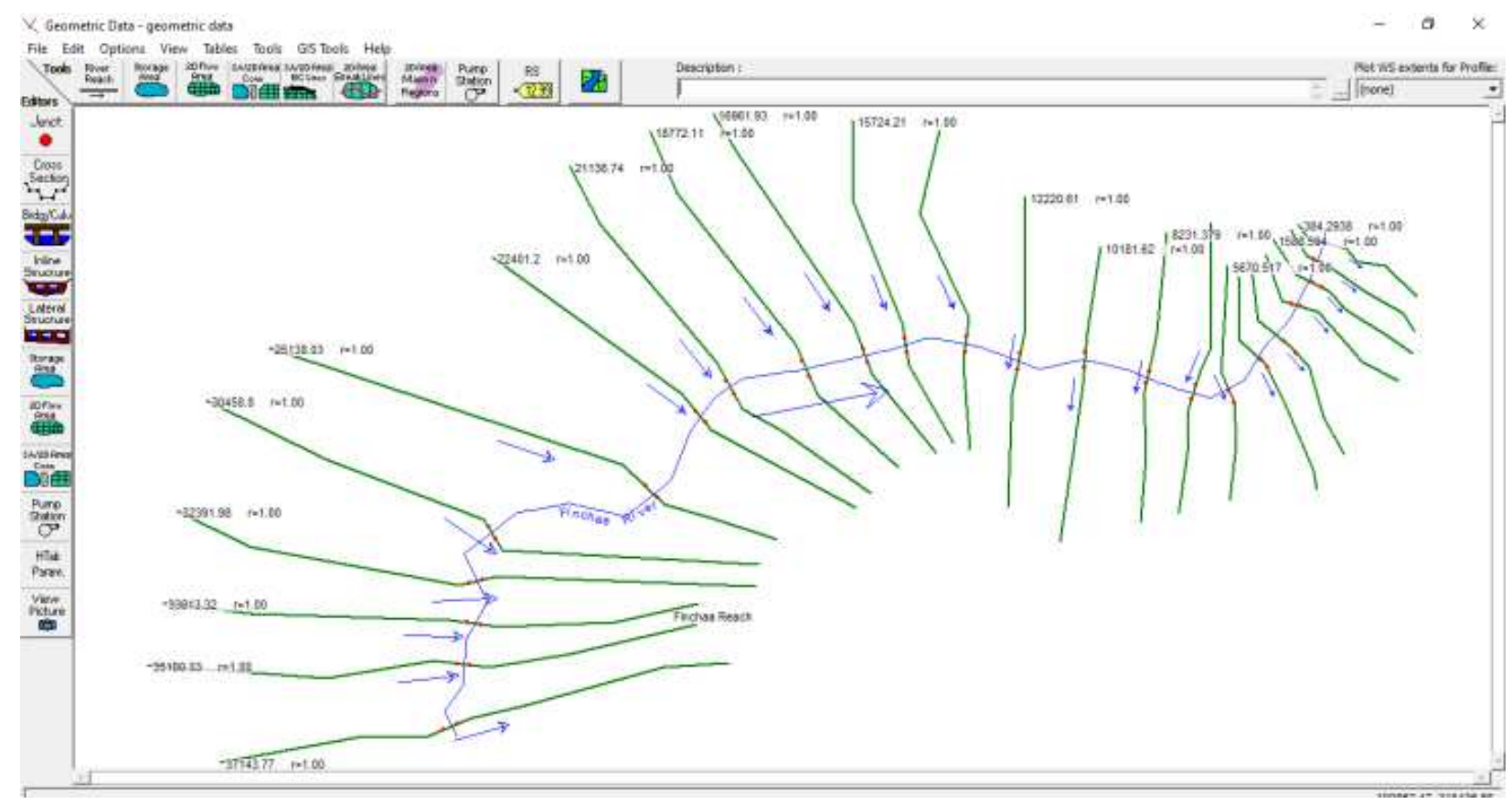

Figure 3. Geometric data Exported from GIS to HEC-RAS model for further analysis.

\subsubsection{Flow Data and Boundary Conditions}

For steady flow models, upstream boundary conditions are input as discharges. Downstream boundary conditions can be set to normal depth, a rating curve, a known water surface elevation, or critical depth. Since no gage data information was available at the downstream end of the model, normal depth was selected for downstream boundary condition. The normal depth option requires an energy slope be entered by the user and the program then back-calculates a starting water surface elevation using Manning's equation.

\subsubsection{Post Processing}

Once the HEC-RAS model was complete, output data was exported to GIS. HEC-GeoRAS was used to compile the data into useful graphical output such as flood inundated prone area.

Once water surface TIN is created, the rasterization of the water surface TIN and the terrain TIN takes place and the flood inundation plan is delineated where the water surface exceeds the terrain elevations.

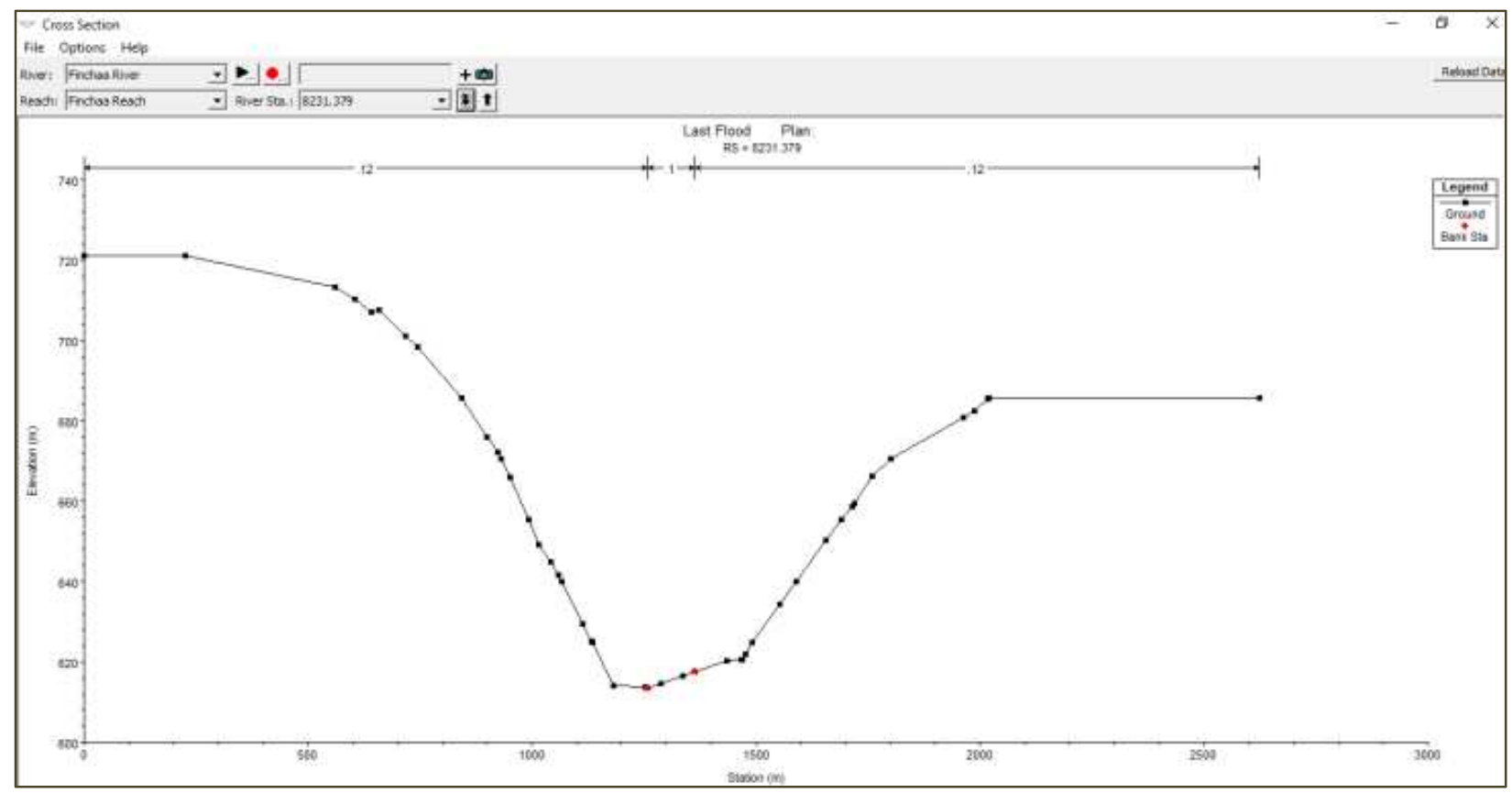

Figure 4. Cross section at different stage of the river through the lake. 


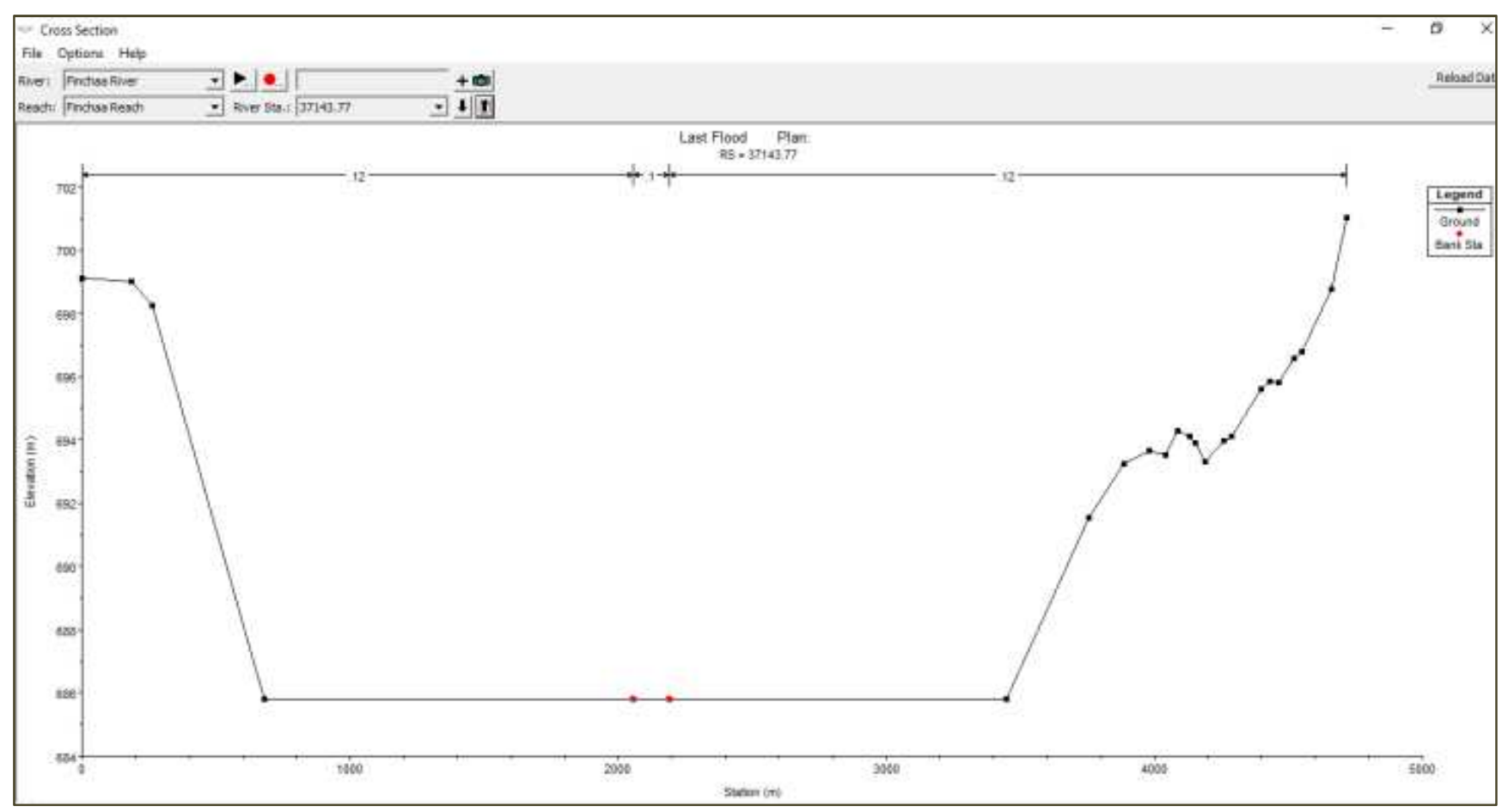

Figure 5. Storage and editing the Manning value in HEC-RAS.

Edit Manning's $n$ or k Values

\begin{tabular}{|c|c|c|c|c|c|}
\hline \multirow{2}{*}{$\begin{array}{l}\text { River: } \\
\text { Reach: }\end{array}$} & \multicolumn{2}{|l|}{ Finchaa River } & \multicolumn{2}{|c|}{ 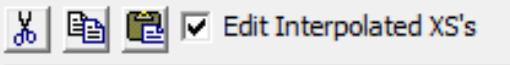 } & \multirow{2}{*}{$\begin{array}{c}\text { Channel } n \text { Values have } \\
\text { a light green } \\
\text { background }\end{array}$} \\
\hline & Finchaa Reach & $\nabla$ & All Regions & $\nabla$ & \\
\hline \multicolumn{6}{|c|}{ Selected Area Edit Options } \\
\hline \multicolumn{2}{|c|}{ Add Constant ... } & Multiply Factor ... & Set Values ... & Replace ... & Reduce to L Ch R ... \\
\hline & River Station & Frctn $(n / K)$ & $\mathrm{n} \# 1$ & $\mathrm{n} \# 2$ & $n \equiv 3$ \\
\hline 1 & 37143.77 & $n$ & 0.12 & 0.1 & 0.12 \\
\hline 2 & 35100.33 & $n$ & 0.12 & 0.1 & 0.12 \\
\hline 3 & 33813.32 & $n$ & 0.12 & 0.1 & 0.12 \\
\hline 4. & 32391.98 & n & 0.12 & 0.1 & 0.12 \\
\hline 5 & 30458.8 & $n$ & 0.12 & 0.1 & 0.12 \\
\hline 6 & 25138.03 & n & 0.12 & 0.1 & 0.12 \\
\hline 7 & 22401.2 & $n$ & 0.12 & 0.1 & 0.12 \\
\hline 8 & 21136.74 & $n$ & 0.12 & 0.1 & 0.12 \\
\hline 9 & 18772.11 & $n$ & 0.12 & 0.1 & 0.12 \\
\hline 10 & 16961.93 & $n$ & 0.12 & 0.1 & 0.12 \\
\hline 11. & 15724.21 & n & 0.12 & 0.1 & 0.12 \\
\hline 12 & 13876.84 & n & 0.12 & 0.1 & 0.12 \\
\hline 13 & 12220.61 & $n$ & 0.12 & 0.1 & 0.12 \\
\hline 14 & 10181.62 & $n$ & 0.12 & 0.1 & 0.12 \\
\hline 15 & 8231.379 & n & 0.12 & 0.1 & 0.12 \\
\hline 16 & 6797.823 & $n$ & 0.12 & 0.1 & 0.12 \\
\hline 17 & 5670.517 & $n$ & 0.12 & 0.1 & 0.12 \\
\hline 18 & 4319.273 & $n$ & 0.15 & 0.1 & 0.15 \\
\hline 19 & 3487.55 & $n$ & 0.15 & 0.1 & 0.15 \\
\hline 20 & 2400.407 & $n$ & 0.15 & 0.1 & 0.15 \\
\hline 21 & 1588.594 & $n$ & 0.15 & 0.1 & 0.15 \\
\hline 22 & 956.0634 & n & 0.15 & 0.1 & 0.15 \\
\hline 23 & 384.2938 & $n$ & 0.15 & 0.1 & 0.15 \\
\hline
\end{tabular}

Figure 6. Manning valus. 


\subsection{Geometric Data Editing}

Geometric data editing involves cross sections, and Manning coefficients. Due to limited data availability, the small tributaries along the different side of the River have not taken into consideration in the computation process. Therefore junction and reach editing of these tributaries to the main channel has not be done. Checking for cross sections has been done based on the surveyed cross-section profile along the Finchaa River through the lake.

\subsection{Steady Flow Analysis}

The simulation has been performed based on the geometric data, flow data and boundary conditions in a steady flow analysis. Steady flow describes condition in which depth and velocity at a given channel location do not change with time. Gradually varied flow is characterized by minor changes in water depth and velocity from cross-section to cross-section.

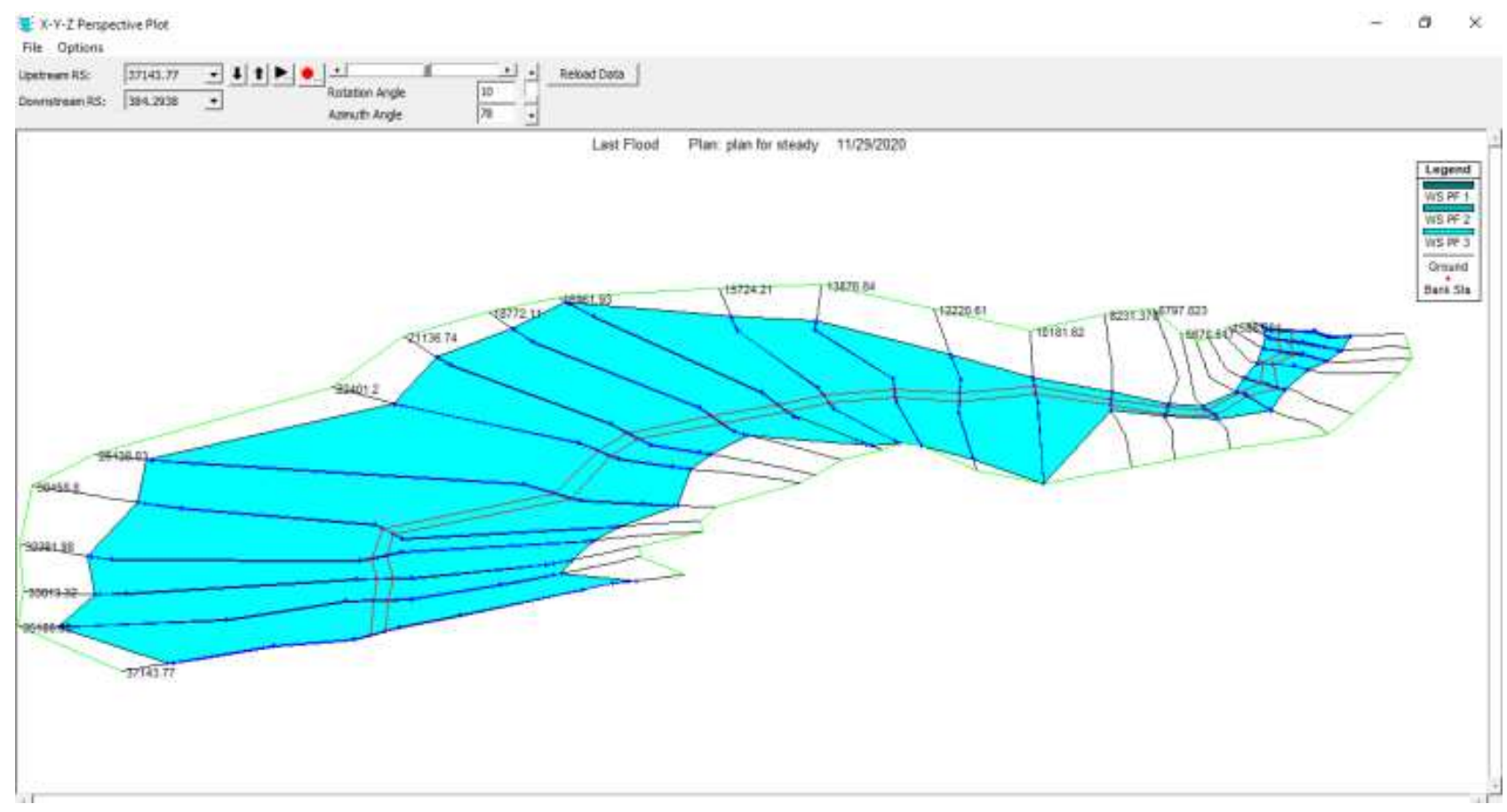

Figure 7. X-Y-Z Perspective for flood spreading.

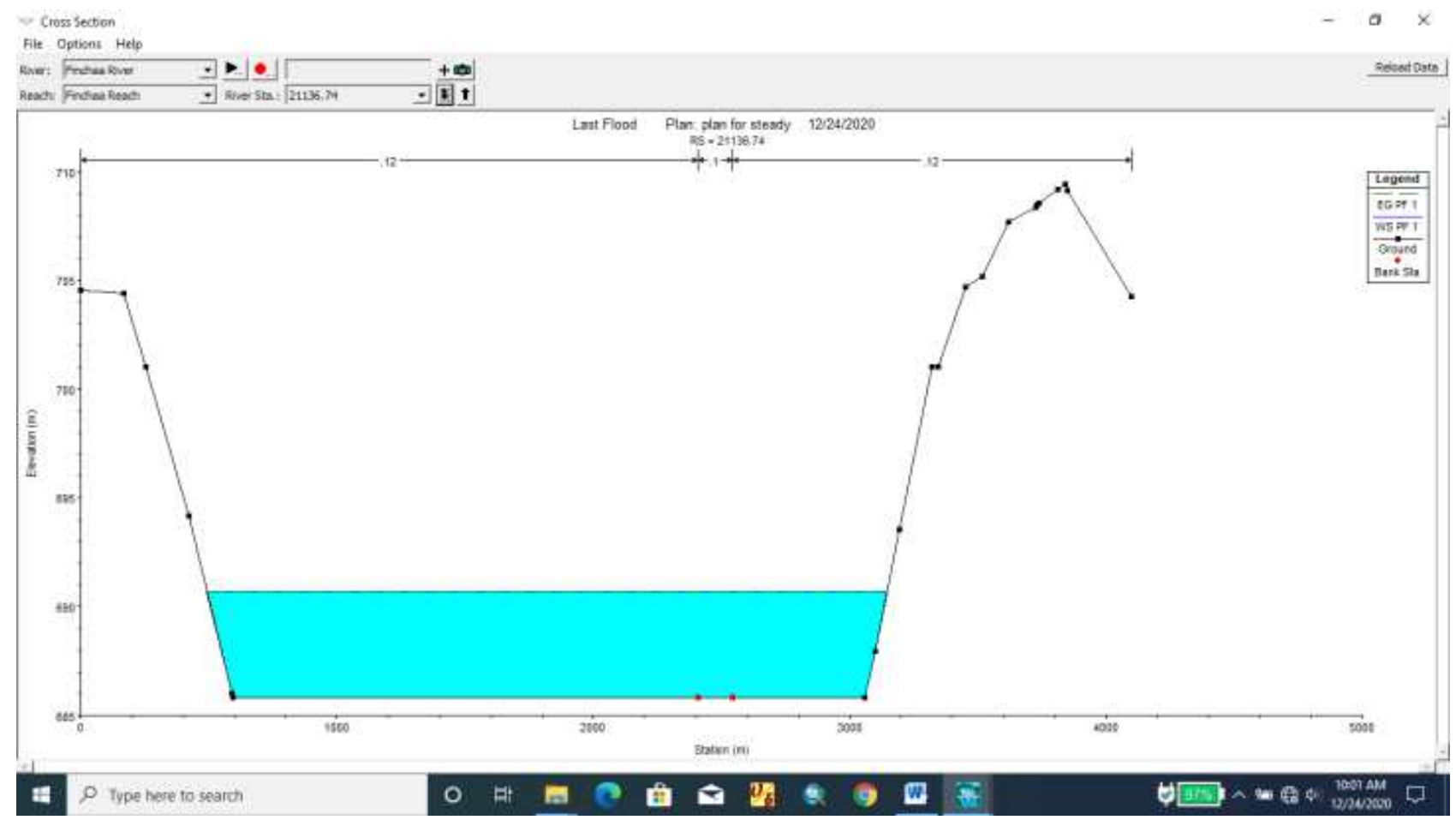




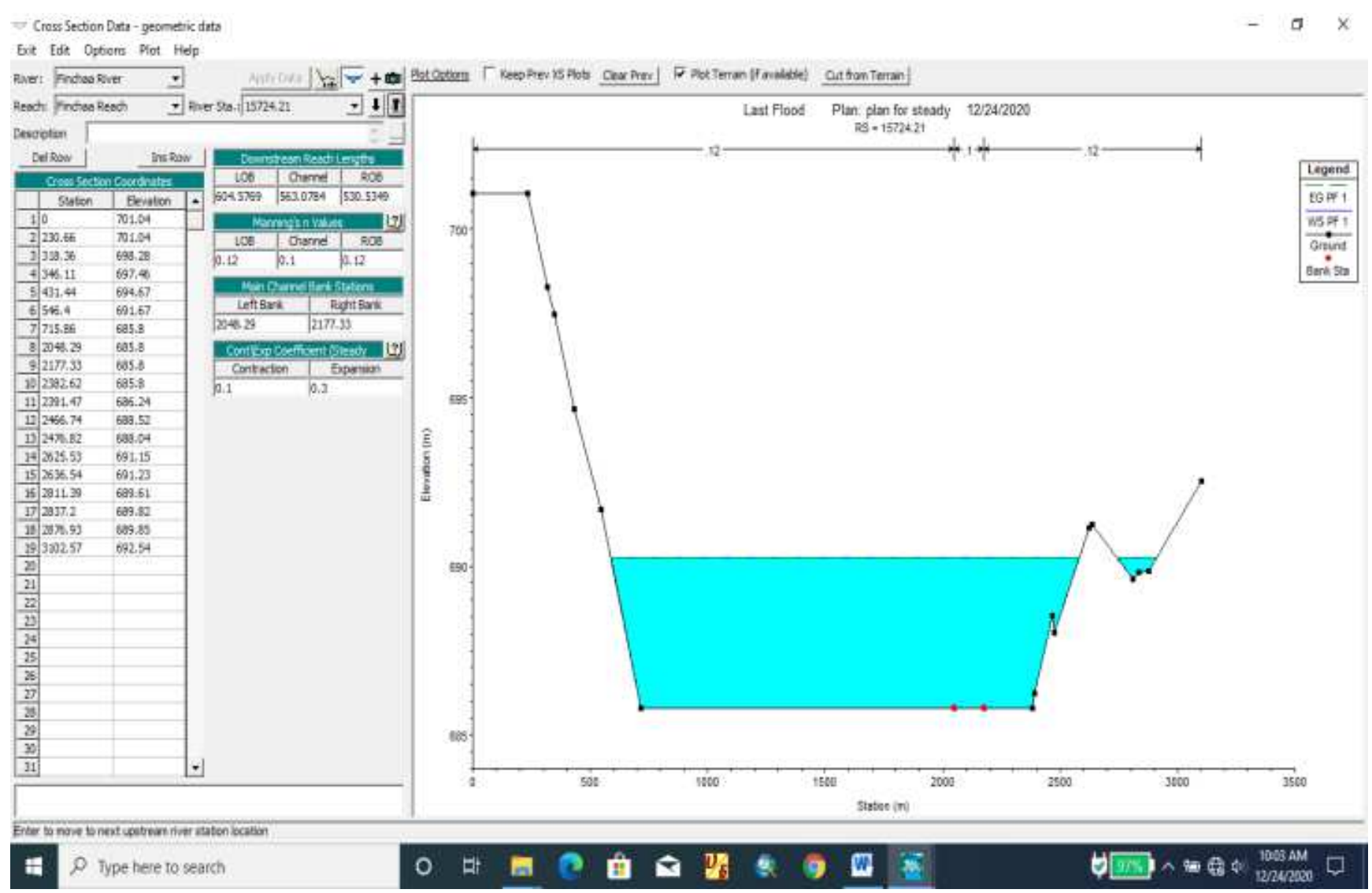

Figure 8. Cross-section after running the model at difference section.

\section{Result and Discussion}

\subsection{DEM Creation}

In case of Finchaa Lake the Digital topographic representation or DEM data were creates from Google Map through GIS software. Contour and TIN data which used for geometric data creation where created from Digital Elevation Model using Arch GIS software tools.

\subsection{Created RAS Themes}

There different lines created those used to represent river analysis system of Finchaa lake such as stream centerline, main channel banks, left over banks, right over banks, flow path center lines, left flow path, right flow path, cross-section cutline as below figure 9 .

\subsection{Created Cross-section}

Cross sections are located at intervals along stream to characterize the flow carrying capability of the stream and its adjacent floodplain. The cross-sections represent the actual values of stream and floodplain geometry. The cross sections are drawn as perpendicular to the stream line.

\subsection{Flood Inundation Area Mapping}

Finchaa lake flooded prone area has been modeled by using maximum water surface level and terrain elevation data. The maximum water level was created in the HEC-RAS Model and flood was delineated by HEC-GeoRAS model in the GIS tool for 100-year return period.

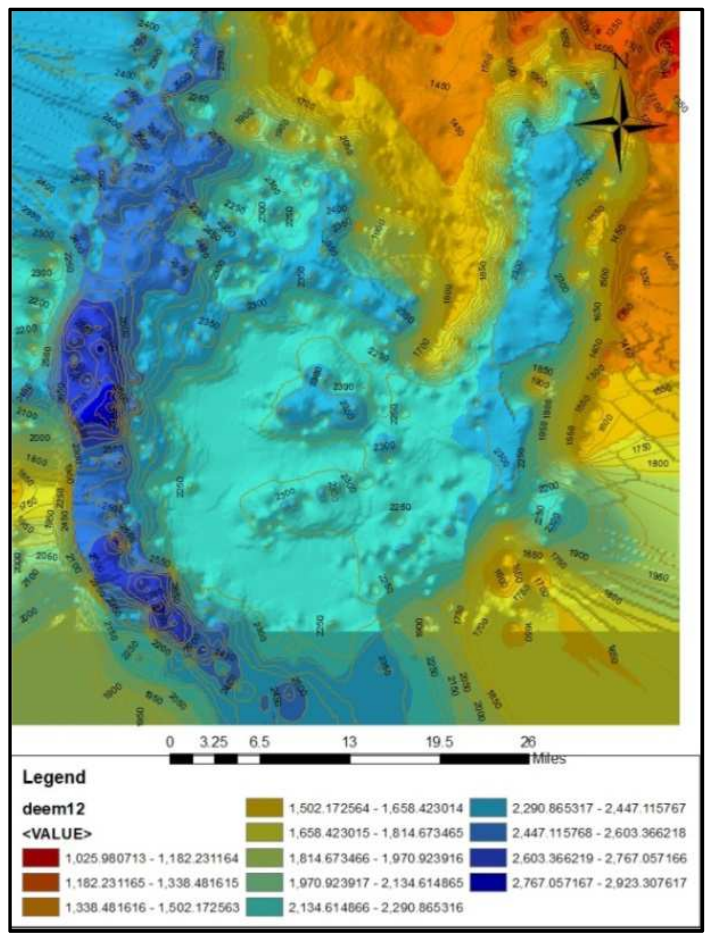

Figure 9. Created DEM and Contour using Google earth. 


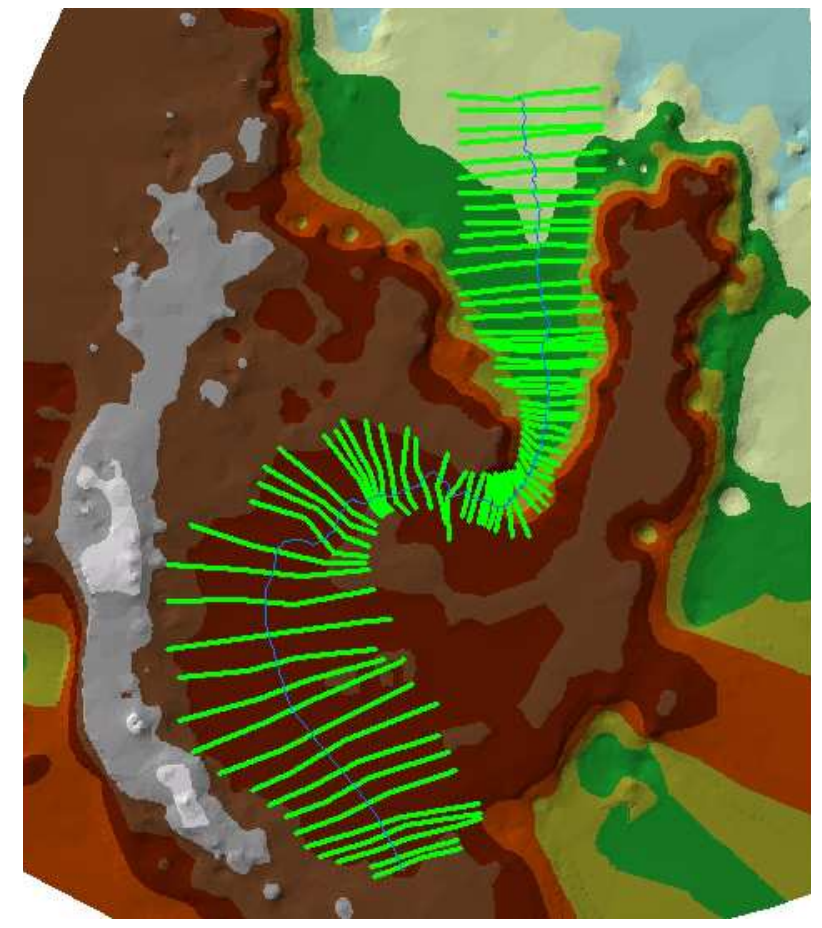

Figure 10. Created cross-section, stream centerline, main channel and main flow path over the TIN.

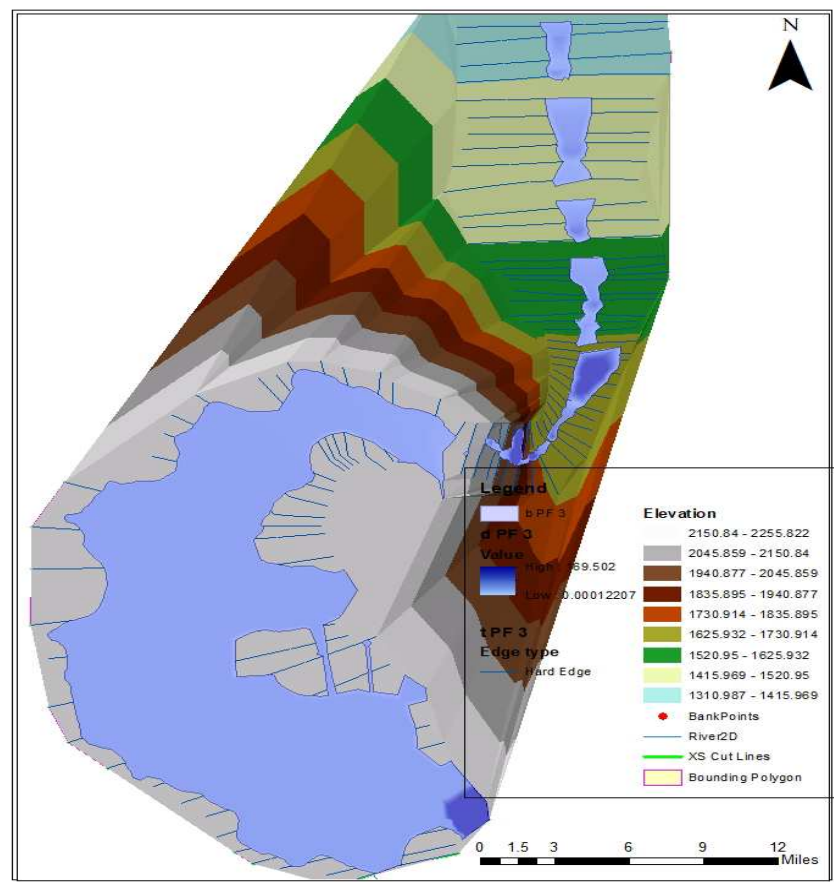

Figure 11. River flood area delineation with TIN.

The distributed flooded depth in the low land area is greater than $10 \mathrm{~m}$ high from mean sea level, which indicates there the probability happing high risk in the downstream are of the lake.

The flood risk of study was measured based on the following factors: depth, speed and width of flood that created during delineation through GIS tools, HEC-GeoRAS and HEC-RAS model.

Flood risk assessment map delineated over $280 \mathrm{~km}^{2}$ shows that where very low land area of the river line where affected the flood and also both side of lakes. This flood coverage area indicates that more than $110 \mathrm{~km}^{2}$ of farming area, grazing area and residential area where under flood risk.

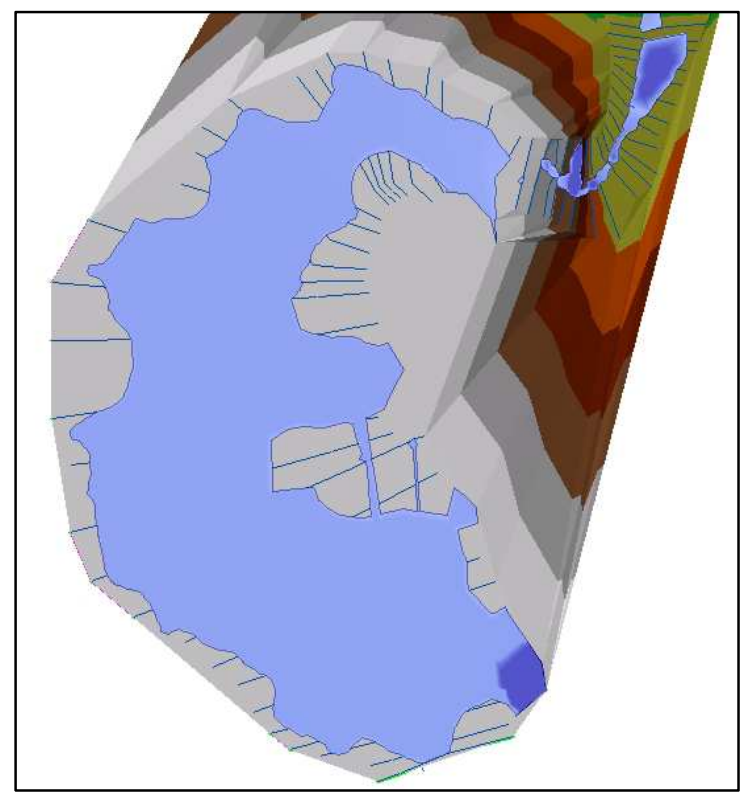

Figure 12. Flood Inundated/ delineated by HEC-GeoRAS over the storage area and the river line.

The probable maximum flood inundated floodplain inside storage and through the river line of lake which covers in the upper and downstream part of the Finchaa Lake and flooded area approximately covers $280 \mathrm{~km}^{2}$ figures 11 . The 50 year return period floodplain map that projected from the probable maximum flood inundated floodplain inside storage and through the river line which covers $230 \mathrm{~km}^{2}$. The flood map projected from the 25 -yearb return period that projected from the probable maximum flood inundated floodplain inside storage and through the river line which covers Finchaa lake and the flooded area approximately covers $205 \mathrm{~km}^{2}$. The 10 year return period floodplain map that projected from the probable maximum flood inundated floodplain inside storage and through the river line which covers $180 \mathrm{~km}^{2}$. Therefore from this result especially downstream parts of lake side were affected by food.

Flood Inundation mapping was mapped using a GIS tools, Hydraulic Engineering center of River Analysis System and Hydraulic Engineering center of Geographic River Analysis System. The flood inundation map shows flood risk areas that affected highly due to occurrence of maximum flood discharges.

\section{Conclusion and Recommendation}

\subsection{Conclusions}

In this study, a Flood inundation mapping and risk analysis of Finchaa Lake have been created using hydrological model (Hydraulic Engineering center of River Analysis System and Hydraulic Engineering center of Geographic River Analysis 
System) and Geographical information system tools. Different input data's are prepared for flood modeling: DEM, geometric data, and hydrological data. Flood inundated prone area were desalinated by using Hydraulic Engineering center of Geographic River Analysis System in GIS software. These results guide planners and administrators to analyze and manage flood risk, and also to develop flood risk management strategy. Measure areas of lakes were flooded area and its effect is evaluated by flood inundation prone area, flood depth and velocity.

Geometric data used for the simulation was created from Google map using different models. Finchaa Lake has been used in the flood delineation. Maximum water level and distributed water width over the lake determined by HECRAS model by using imported geometric data from geographical information system. Flood inundation mapping has been constructed on the basis of cross-sectional data and its risk is analyzed based on the produced flood depth, width and time of occurrence. The HEC-RAS model output maximum water surface level was imported to GIS tools and flood is delineated by HEC-Geo RAS model.

The maximum flood prone area inundated using 100 year return period was the probable maximum flood inundated floodplain along the lake and through the lake which covers and in the upper and downstream part of the Finchaa Lake and flooded area approximately covers $280 \mathrm{~km}^{2}$ and based on the inundated flood mapping flood risk is analyzed.

\subsection{Recommendations}

There are different agricultural areas both sides and downstream of the Finchaa Lake that should protected from the flood prone area of these lakes. Since the sediment accumulation is the major cause of the flood inundation, it very crucial to project it from the lake and it is recommended to study sediment accumulation of these reservoirs. The dam owners and emergency management authority should guide communities those living and farming both sides of the lake by using map of flood prone areas. Information on flood inundation area is important in flood risk management. Creating flood inundation maps involves hydrologic modeling and hydraulic modeling; and topographical terrain analyses. The following recommendations indicate some of the aspects of improving flood inundation modeling for further research:

Researcher should include the hydrological analyses such as estimation of reservoir sediment accumulation, inflow hydrograph of these rivers and daily loosed water.

Extra research should be done by consider other variables for calibration and validation process. In developing the flood inundation map and risk analysis of lake, the accuracy is important.

\section{References}

[1] Kalyanapu AJ, B. S. (2009). Effect of land use-based surface roughness on hydrologic model output. Journal of Civil \& Environmental Engineering.

[2] Kvočka D, F. R. (2015). Appropriate model use for predicting elevation and inundation extene fore extream flood event. Journal of Civil and Environmental Engineering, 79.

[3] Şen Z, K. H.-H.-A.-B. (2013). Flood inundation map preparation for wadis in arid regions. Journal of Civil and Environmental Engineering, 6.

[4] Ghanbarpour MR, S. S. (2008). Flood Inundataion Mapping uing hydraulic simulation model in GIS. Journal of Since and Environmental.

[5] Sterk, B. T. (2008, Feburary). Hydropower-Induced Land Use Change in Finchaa Watershed, Analysis and Impacts. Mountain Reserch and Development, 28 (1): 72-80.2008, 2, 73.

[6] Brunner, G. W. (2010). HEC-RAS, River Analysis System Hydraulic Reference Manual. United State of America: U.S Army Corps of Engineer.

[7] Forkuo, E. K. (2011). Flood Hazard Mapping using Aster Image data with GIS. INTERNATIONAL JOURNAL OF GEOMATICS AND GEOSCIENCES, 936.

[8] Source Ministry of Water, Irrigation and Energy. (1973). design of finchaa dam fesibility study. Addis abeba.

[9] Gemechu. et al, (2020). Geographic Information System (GIS)-Based multicriteria analysis of flooding hazard and risk in Ambo Town and its watershed, West Shoa Zone, oromia regional State, Ethiopia, Journal of Hydrology.

[10] Shabnam, M. Z. (2020). Detection of trends in flood magnitude and frequency in Canada, Journal of Hydrology.

[11] Sina A, R. A. (2010). GIS-based River Flood Hazard Mapping in Urban Area, International Journal of Engineering and Technology.

[12] Goodell, C. W (2016). Flood Inundation using HEC-RAS, West consultant. 